\title{
TITLE:
}

\section{MUSCULAR ACTIVITY OF THE ACONTIUM OF SEA ANEMONE}

$\operatorname{AUTHOR}(\mathrm{S}):$

Wada, Tuneyo

\section{CITATION:}

Wada, Tuneyo. MUSCULAR ACTIVITY OF THE ACONTIUM OF SEA ANEMONE. PUBLICATIONS OF THE SETO MARINE BIOLOGICAL LABORATORY 1973, 20: 597-613

ISSUE DATE:

1973-12-19

URL:

http://hdl.handle.net/2433/175755

RIGHT: 


\title{
MUSCULAR ACTIVITY OF THE ACONTIUM OF SEA ANEMONE
}

\author{
TUNEYO WADA \\ Department of Biology, Ochanomizu University, Tokyo, and \\ Tateyama Marine Laboratory, Tateyama, Chiba Prefecture
}

With Plate I and 13 Text-figures

In the past, great names in zoology such as those of the Hertwigs, Carlgren and G. H. PARKer have been associated with the acontium, but in recent years this organ seems rather neglected among actinian biologists, remaining in service only for taxonomists as a diagnostic symbol. However, the present author has found that the acontial filaments of Diadumene and Metridium not only respond to external stimuli such as stretching, cutting, or agitation by a current of sea water from a pipette, but also exhibit more or less periodic contractile activity of the acontial muscles.

YANAGITA and WADA (1959) have presented a diagrammatic reconstruction of the histological details of the Diadumene acontium as seen in cross-section. It is built on a bilateral plan (like a worm), with the "dorsum" loaded with cnidae and the "ventrum" containing a pair of longitudinal muscle bands. This muscle works against the elasticity of the "dorsad" structures, including the mesogloeal core, and its state of activity can be quantitated by measuring the local curvature of an excised and freely lying acontial filament.

One of the interesting subjects might be to see if the "decremental" propagation as seen in the semi-rhythmic spontaneous contraction of the acontial muscles in due to junctional facilitation.

Being a singularly simple specimen and ready-made linear preparation of muscular and, probably, nervous elements, the acontium is expected to do service for the physiologist, also.

\section{The Nerves and Muscles of "Acontia"}

The Hertwigs (1879) reported that a longitudinal muscle band was to be seen on the outer face of the T-shaped cross arm of the mesogloeal axis of an acontium. This was demonstrated in a transverse section of the acontium of a species of Sagartia, but the observations made by PARKer and Titus (1916) of the acontia of the closely allied genus Metridium failed to agree with those of the Herwwigs. According to these authors, the longitudinal muscle band is situated at the side of the T-shaft. This observation agreed with CARLGREN's (1893) (Fig. 1) description of the acontia of Metridium dianthus and Sagartia viduata, which suggested that the HERTwIGs were mistaken 
T. WADA

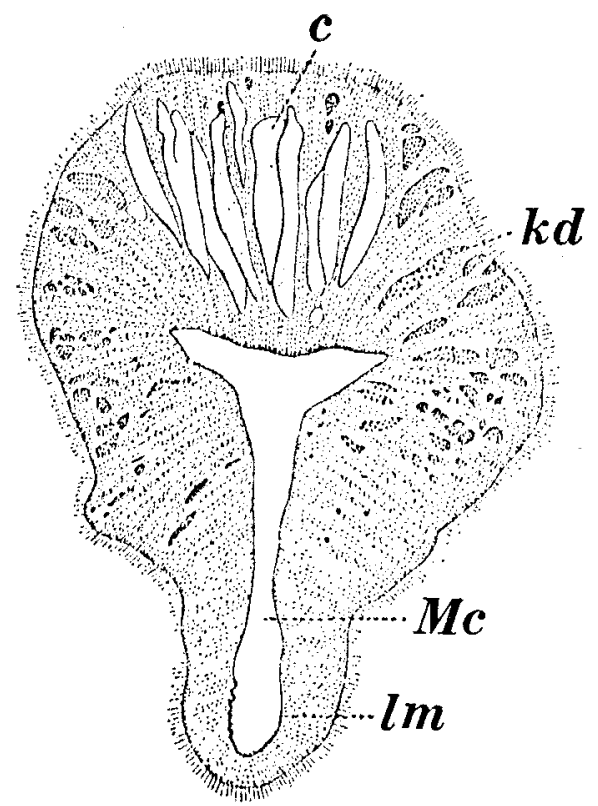

Fig. 1. CARlgen's diagram of the cross-section of the acontium of Sagartia viduata.

c: nematocyst; $\mathrm{kd}$ : gland cell; $1 \mathrm{~m}$ : longitudinal muscle fibers; mc: mesogloeal core. Reproduced from CARLGREN (1893). (cited from PARKer and Titus, 1916).

YANAGITA and WADA (1959) have presented a diagrammatic reconstruction of the Diadumene acontium as seen in cross-section (Fig. 2) and WADA (1972) demonstrated that the longitudinal muscle bundle of Metridium acontium (Figs. 3, 4) corresponds to that indicated in CARLGREN's (1893) drawing of the Sagartia acontium.

There has been some disagreement as to whether nerves exist in acontia and, if they do exist, whether they play any significant part in initiating and controlling musclar activity. The HeRTwigs (1879, p. 562) regarded a thin layer of punctate substance (Taf. 21, Fig. 11), which was just external to each row of muscle fibers, as representing the cross-section of the nervous elements of the Sagartia acontium. PARKER and

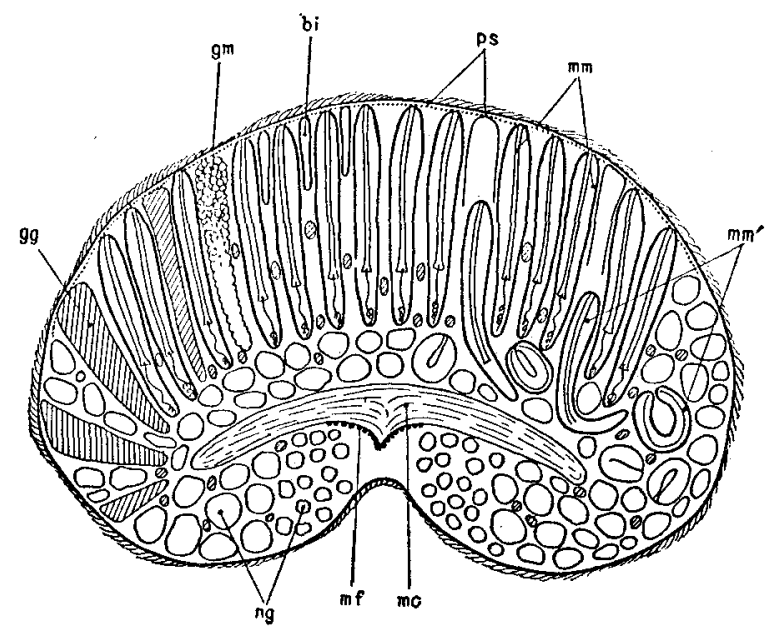

Fig. 2. Diagrammatical re-construction of the microscopical makeup of Diadumene acontium as seen in its cross-section. The left is shown as in a state particularly abundant in "gland cells", and the right half as in a state containing many cnidae in the course of formation. Nuclei are represented by shadowed circlets, and intraprotoplasmic and pigment granules are all omitted. bi: basitrichous isorhiza; gg: gland cell of granular type (?); gm: gland cell of mucous type (?); mc: mesogloeal core; mf: muscle fiber; $\mathrm{mm}$ : microbasic mastigophore; mm': immature mastigophore; ng: neutral-red globule; ps: surface sheet of protoplasm, bearing cilia. Reproduced from YANAGITA and WADA (1959). 

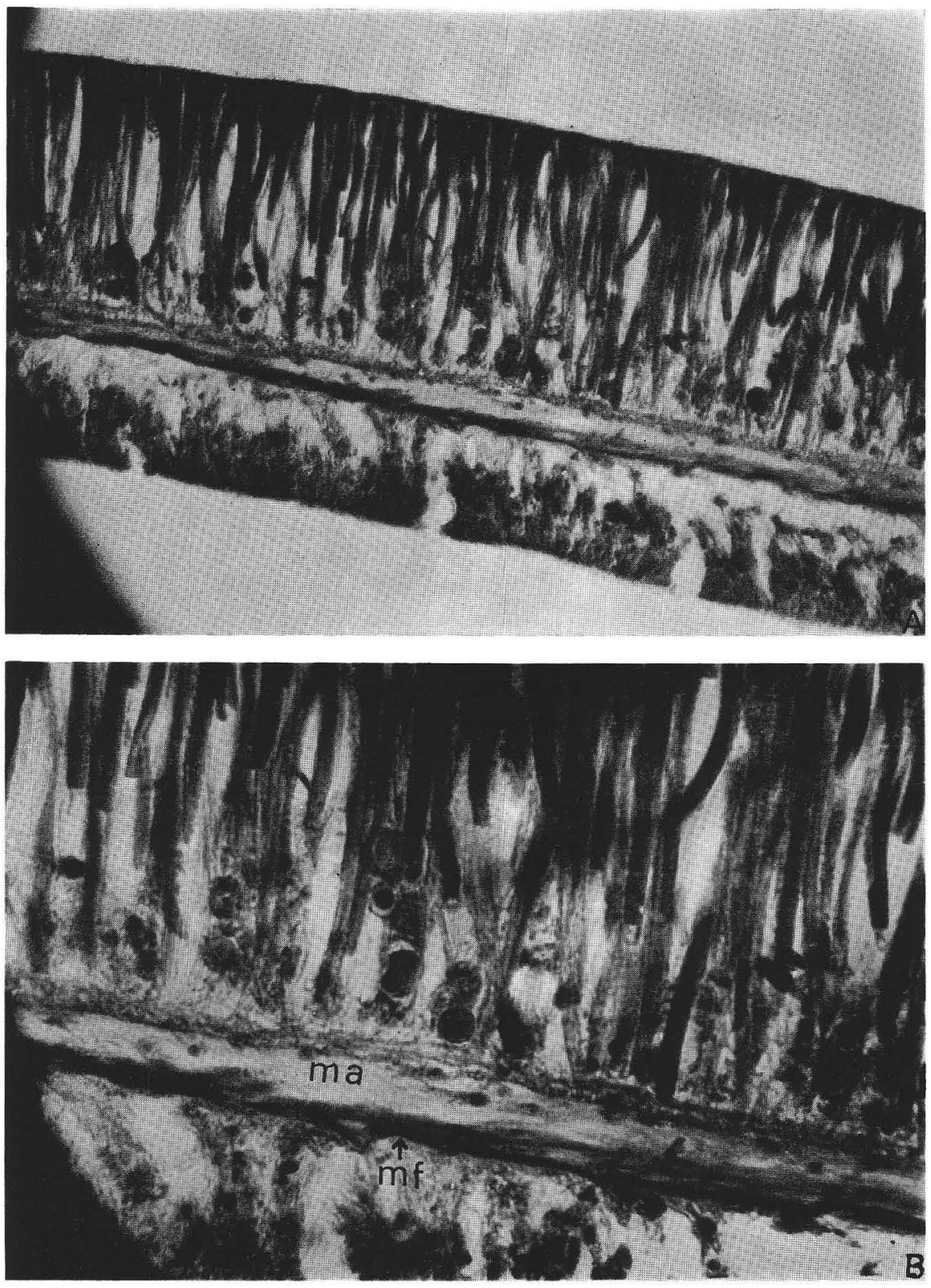

Fig. 3. Longitudinal muscles of the Metridium acontium. The fibres are present in the form of tape- like strands. They develop on the side opposite the array of cnidae in contact with the mesogloea. A: [Microscopical photograph in low power] $\times 320$.

B: [Enlarged photograph of the same preparation] $\times 640$. ma: mesogloeal axis; mf: muscle fibre. 


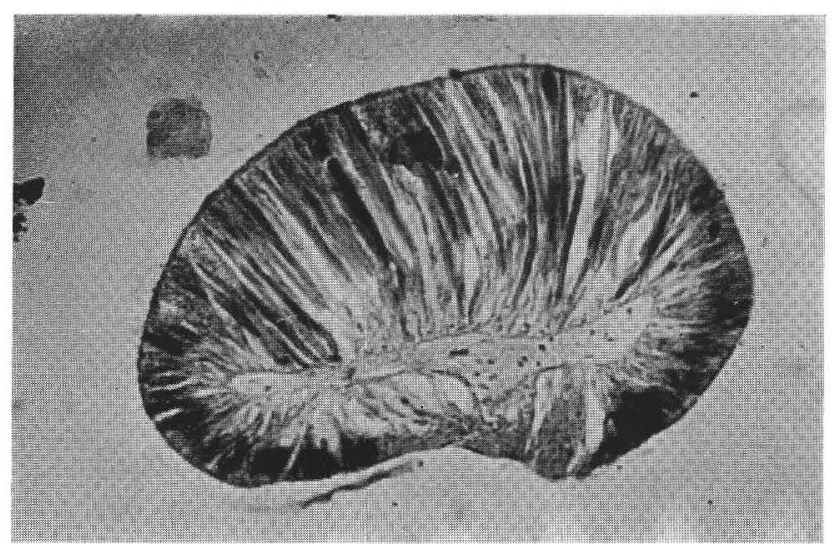

Fig. 4. Cross section of the Metridium acontium, showing the single layers of muscle fibres lying bilaterally in the angles of the T-shaped mesogloeal axis. $(\times 220)$.

TITUs (1916) reported that if a stimulus was applied to one end of a long acontium, only that end responded by becoming snarled. They also found that adequately anesthetized acontia became snarled to the same extent as unanesthetized acontia when flooded with meat juice. From these observations PARKER concluded that neural elements played no significant role in the acontia of Metridium, and that their muscles responded directly to external stimulation.

One attempt was made by the present author (WADA, 1972, in manuscript) to identify nervous elements in the Diadumene acontium. Vital staining with reduced methylene blue by UNNA's method modified by MACCONNELL (1932) was used. Bipolar cells were observed, which have soma about 10 to $15 \mu$ in length and about 3 to $5 \mu$ in width (Plate I). The processes of the bipolar cells are from 10 to $60 \mu$ long. These cells are distributed on the mesogloeal band at intervals of 200 to $300 \mu$. Longitudinal connections between the processes were not observed, but in many cases the processes of two or three adjacent cells appeared to be attached to each other.

\section{Spontaneous Contractile Activities of the Diadumene Acontium}

\section{Attached Acontia}

When Diadumene is stimulated by pressure applied to the body wall with a forceps, the acontia are extruded through the cinclides or mouth. In such attached acontia, as soon as they were extruded, strong coiling was initiated in the proximal part and rapidly propagated to the distal part of the filament. After these coils had been maintained for a rather long period ( 1 to 3 minutes), the filaments began to uncoil from the distal to the proximal part. When observation of the contractile activities of attached filaments was performed under constant artificial light (about 400 lux) at room temperature $\left(18-24^{\circ} \mathrm{C}\right)$ and with special precautions to keep the animal in a quies- 
cent state, strong contraction (three-dimensional coiling) was sometimes observed (at about 10-minute intervals), but local bending or weak coiling of the filaments was initiated more frequently. These coiling and uncoiling activities continued until the acontia were retracted into the gastric cavity. The time required for the acontia to be withdrawn varied widely, from 10 minutes to several hours.

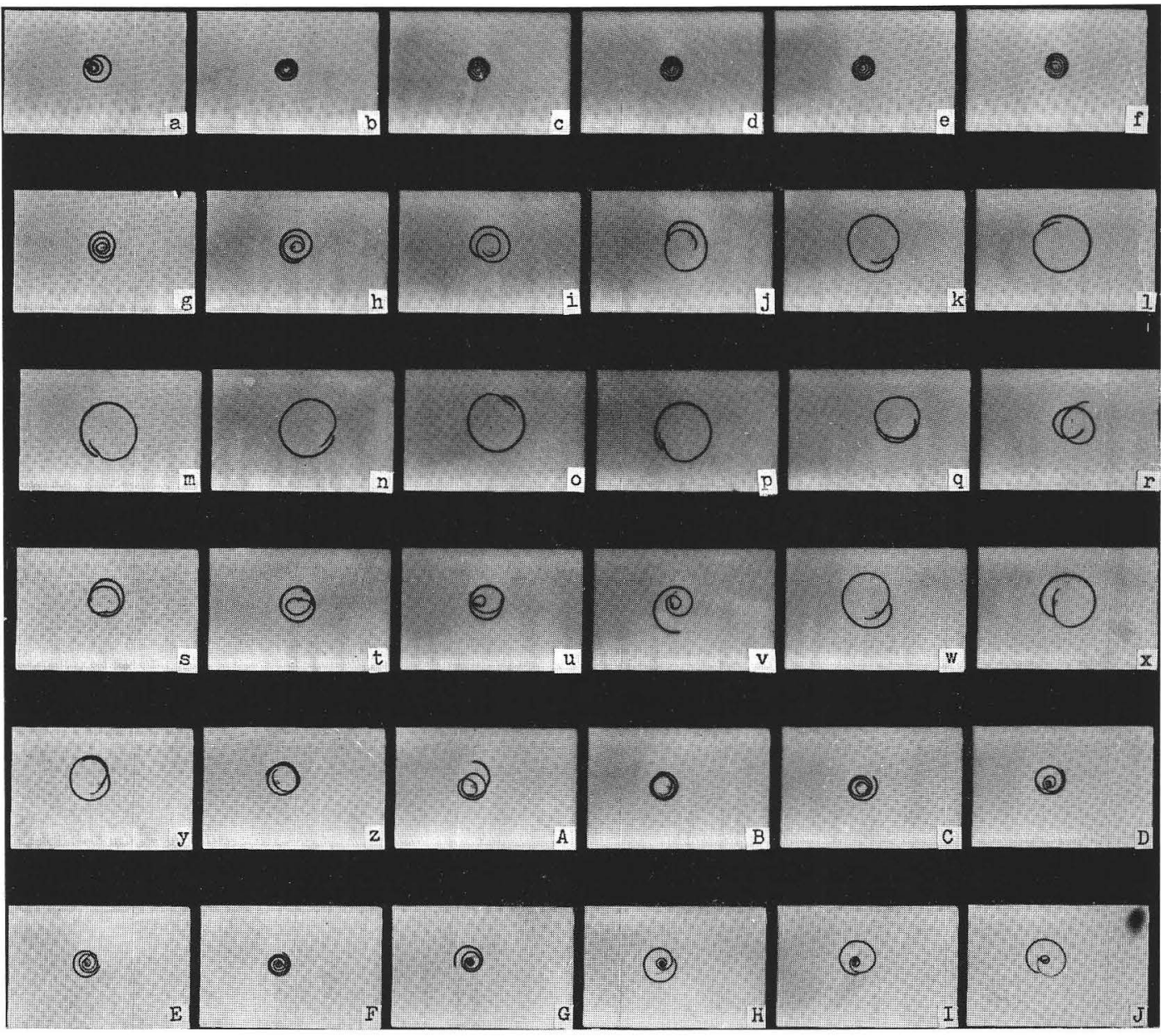

Fig. 5. Spontaneous contractile activities of the Diadumene acontium photographed at intervals of $10 \mathrm{sec}$. Three degrees of contractile strength are recognized: " 3 " (close coiling), as seen in b-f, F; "2" (loose coiling), a, g, E, G; "1" (curling). k-p, W-X.

\section{Isolated Acontia}

Filaments about $10 \mathrm{~mm}$ in length were cut off at the base and transferred to $1 \mathrm{cc}$ of sea water on a depression slide provided with intake and outlet tubes. Observation was performed through a floating magnifier (x 1.5) under the same condition as in the case of attached acontia. 
Cutting or agitation of the isolated filaments induced snarling or strong coiling, which began to regress after about 10 minutes. In these isolated acontia, the frequency and strength of the semi-rhythmic coiling and uncoiling of the filament were measured. Measurement of frequency was done by the following method. The time when an acontium began to coil or uncoil was observed with a stop watch, over a period of 30 minutes. Using these data, each time interval from the beginning of coiling to the beginning of uncoiling was calculated and their mean values were obtained for five acontia. The mean values of the periods from the beginning of coiling to the beginning of uncoiling, expressed in terms of "contraction phase" (C), and the mean values of the period from the beginning of uncoiling to the beginning of coiling, expressed in terms of "relaxation phase" $(\mathrm{R})$, were obtained. The frequency of contraction was calculated from the converse of $\mathrm{C}+\mathrm{R}$.

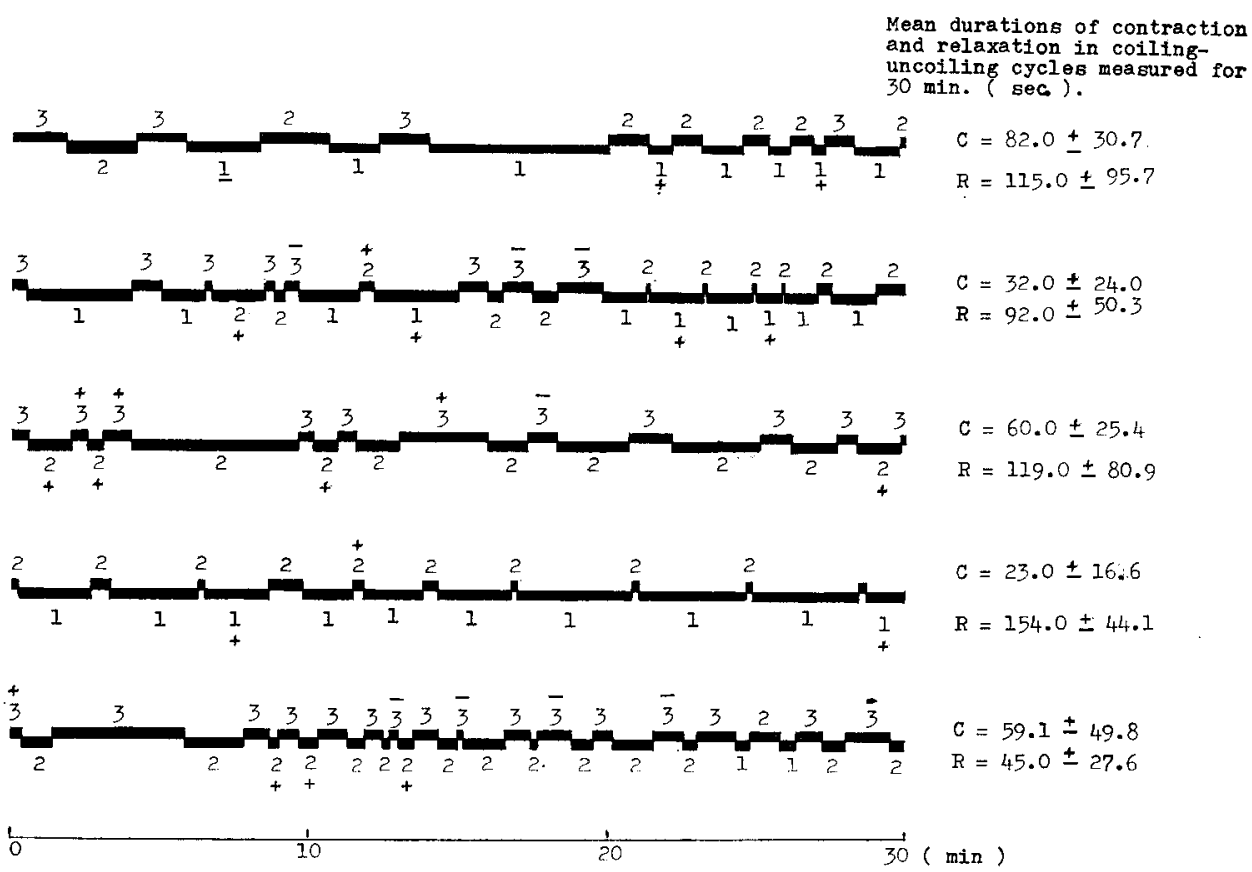

Fig. 6. Diagram of the semi-rhythmic contractile activities of 5 isolated acontial filaments of Diadumene. The upward dark bars represent the duration of the contraction phase (C) and the downward bars show the duration of the relaxation phase (R). The numbers represent the grade of contraction strength. Intermediate degreesof contraction are indicated by + or - .

Besides measuring the frequency of contraction, the strength of contraction was graded by assigning a rating from " 1 " to " 3 " according to the degree of coiling. When the acontium was curled as shown in Fig. 5, $\mathrm{k}$ to $\mathrm{p}$, the intensity of its muscular contraction was rated "1". Tight coiling as shown in Fig. 5, b to f, was rated "3" and 
loose coiling of the acontium was rated " 2 ". These recordings of frequency and intensity were made as nearly simultaneously as possible. The results obtained for frequency and strength show that these contracting and relaxing activities have a more or less regular rhythm (Fig. 6).

\section{Propagation of the Spontaneous Muscle Contraction of the Diadumene Acontium}

To determine the propagation rate $(V=s / t)$ of muscular contraction of the acontial filament, the range $(s)$ and the time $(t)$ required for the propagation must be measured as in general cases for determining the propagation rate. Since the spontaneous muscular contraction of the filament induced coiling of its proximal part which propagated distally, the propagation range was determined by measuring the local curvature of the filament. It was proved that the curvature (c) was in direct propotion to the contraction rate $(S)$ of the coiling filament as shown in following eqation.
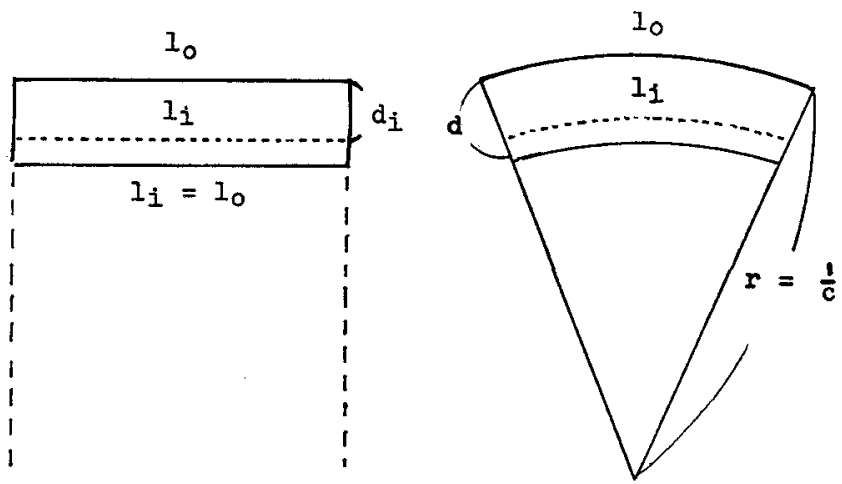

Fig. 7. Diagrams of relaxed and contracting acontial pieces to show method of calculating degree of contraction. $c$ : the curvature at convex side of contracted piece. $d$ : diameter of acontial piece. $d_{i}: d \times 2 / 3$, to correct for position of muscle band in relation to piece diameter. $\mathbf{1}_{i}$ : length of inner side corresponding to the position of the muscle band. $\mathbf{1}_{0}$ : length of convex side of contracted piece. $r$ : radius of circle having arc which fits to convex side of contracting piece.

$$
S=c . d \times \frac{2}{3}
$$

$c$ represents the curvature on convex side of a segment of the coiling filament. $d \times \frac{2}{3}$ represents the diameter of the filament corrected for the position of the muscle bundle.

Equation (1) was induced by geometrical calculation of the coiling filament (Fig. 7) as follows: 


$$
\begin{array}{lc}
S=\frac{l_{0}-l_{i}}{l_{0}}, & S=\frac{\triangle l_{0}}{l_{0}} \quad\left(l_{0}-l_{i} \text { was substituted by } \triangle l_{0}\right), \\
\frac{l_{0}}{r}=\frac{l_{i}}{r-d_{i}}, & \frac{l_{i}}{l_{0}}=\frac{r-d_{i}}{r}, \\
\frac{l_{0}-\triangle l_{0}}{l_{0}}=\frac{r}{r}-\frac{1}{r} \cdot d_{i} \quad\left(l_{0}-\triangle l_{0} \text { was substituted for } l_{i}\right), \\
\frac{\triangle l_{0}}{l_{0}}=\frac{1}{r} \cdot d_{i} \quad\left(d_{i}=d \times \frac{2}{3}\right), \\
S=\frac{\triangle l_{0}}{l_{0}}=\frac{1}{r} \cdot d \times \frac{2}{3} \quad\left(\frac{1}{r}=c\right), & S=c . d \times \frac{2}{3}
\end{array}
$$

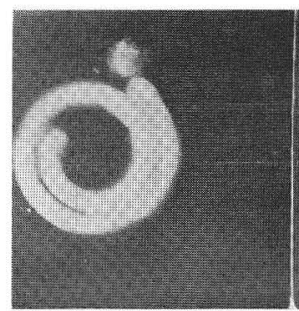

0

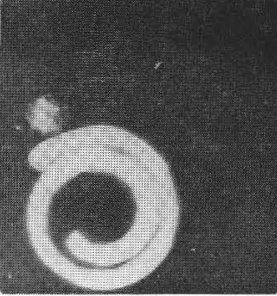

4

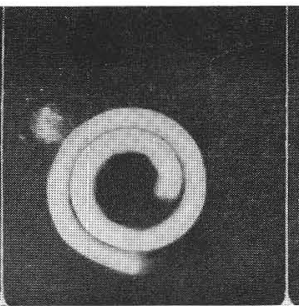

8

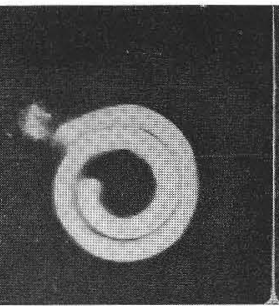

12

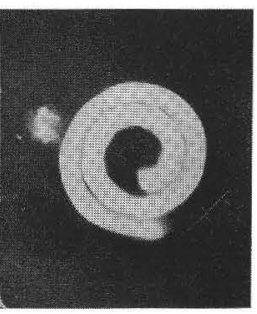

16

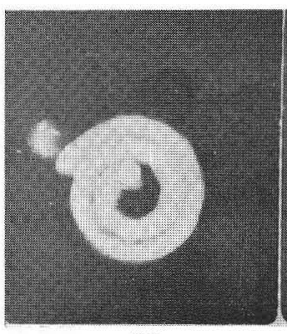

20

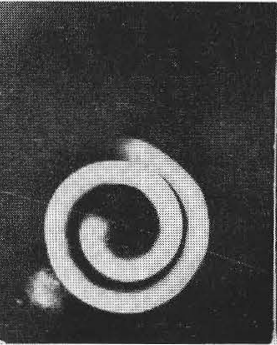

40

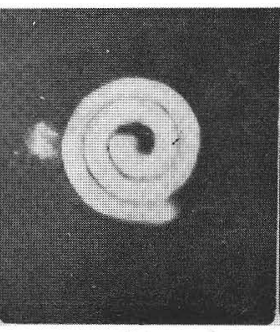

24

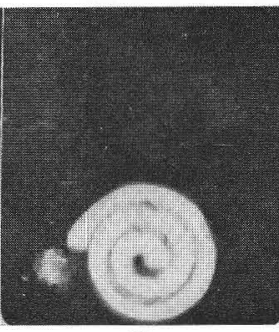

28

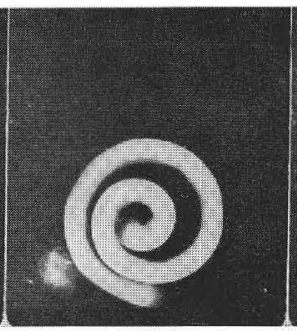

32

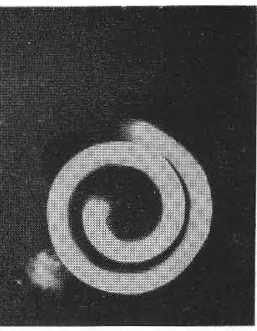

36

Fig. 8. Spontaneous contracting segment of Diadumene acontium photographed at 4-second intervals. 
The curvature $(c)$ was measured by the following method. A single contracting acontium was photographed at 4-second intervals (Fig. 8) and the curvature of the coils was measured by marking off the outer length of obtained picture into 5 segments

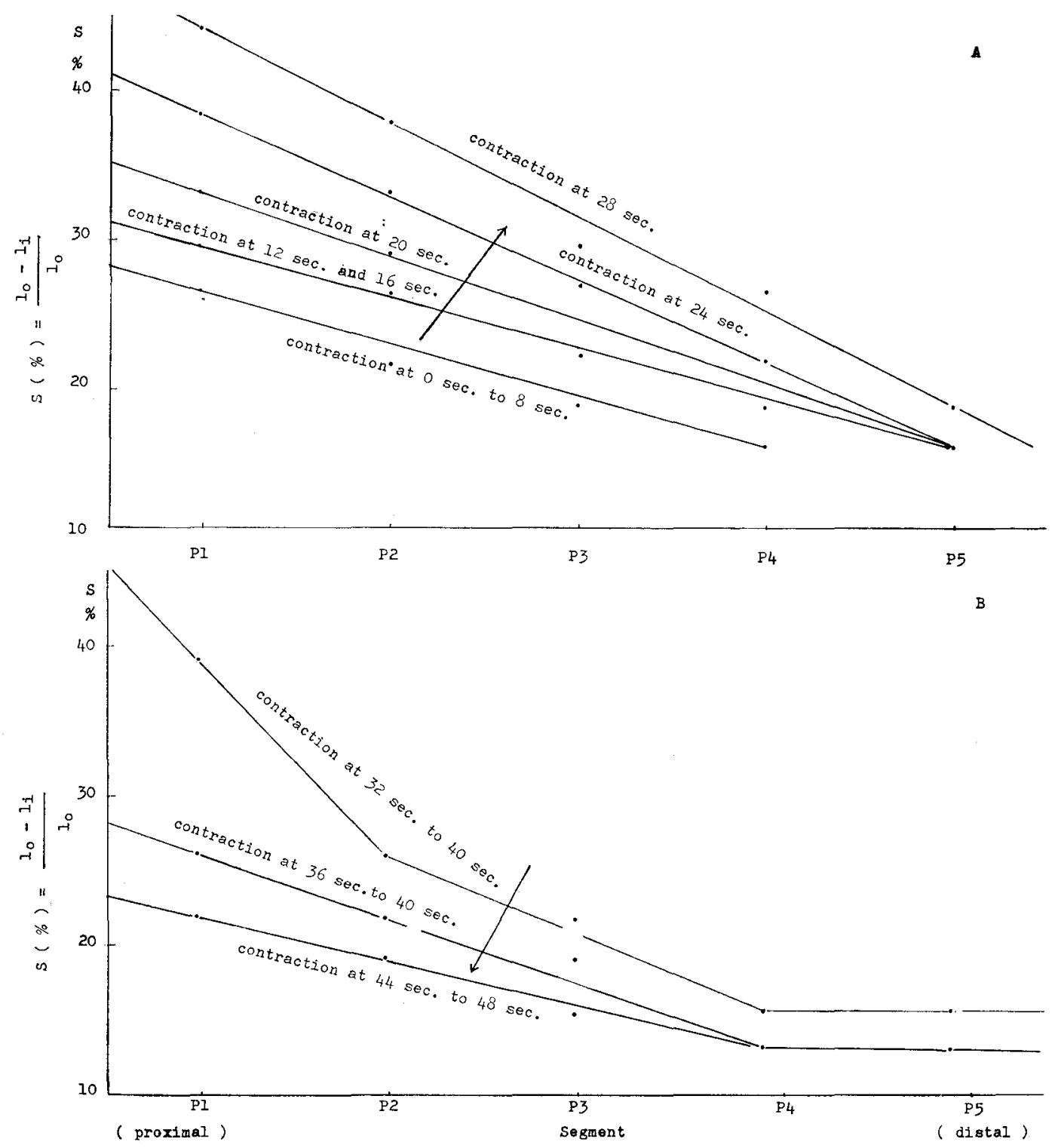

Fig. 9. Contraction rate of the spontaneous muscular activities of each part of one acontial filament of Diadumene luciae marked off into 5 segments. A. "contraction phase", increasing of the contraction rate with time course. B. "relaxation phase", decreasing of the contraction rate with time course. The line represents the total length of the acontial piece. The numbers under the line show the order of the series of 5 segments. 
with a curvimeter, and matching the position $\left(l_{i}\right)$ of each segment with its counterpart in a series of concentric circles of known diameter drawn $1 \mathrm{~mm}$ apart. The contraction rate $(S)$ was calculated from the equation (1). The contraction rates obtained are shown in Fig. 9.

The propagation rate $(V)$ of the muscular contraction of the acontium was represented by the equation:

$$
\mathrm{v}=s / t
$$

$s$ shows the propagation range $(\mu)$,

$t$ shows the time required for propagation (sec.).

The propagation range $(s)$ was obtained from the number of segments over which contraction propagated (Fig. 10). The 4 points on the ordinate at $12 \mathrm{sec}$. show the increase in contraction propagated from the proximal segment (P1) to the fourth segment (P4) during 4 seconds. In the same way, the contraction at $16 \mathrm{sec}$. also propagated to the fourth segment ( $\mathrm{P} 1$ to $\mathrm{P} 4$ ), during 4 seconds. At $20 \mathrm{sec}$., the contraction propagates over only two segments (P1 to P2). At 28 sec., however, an

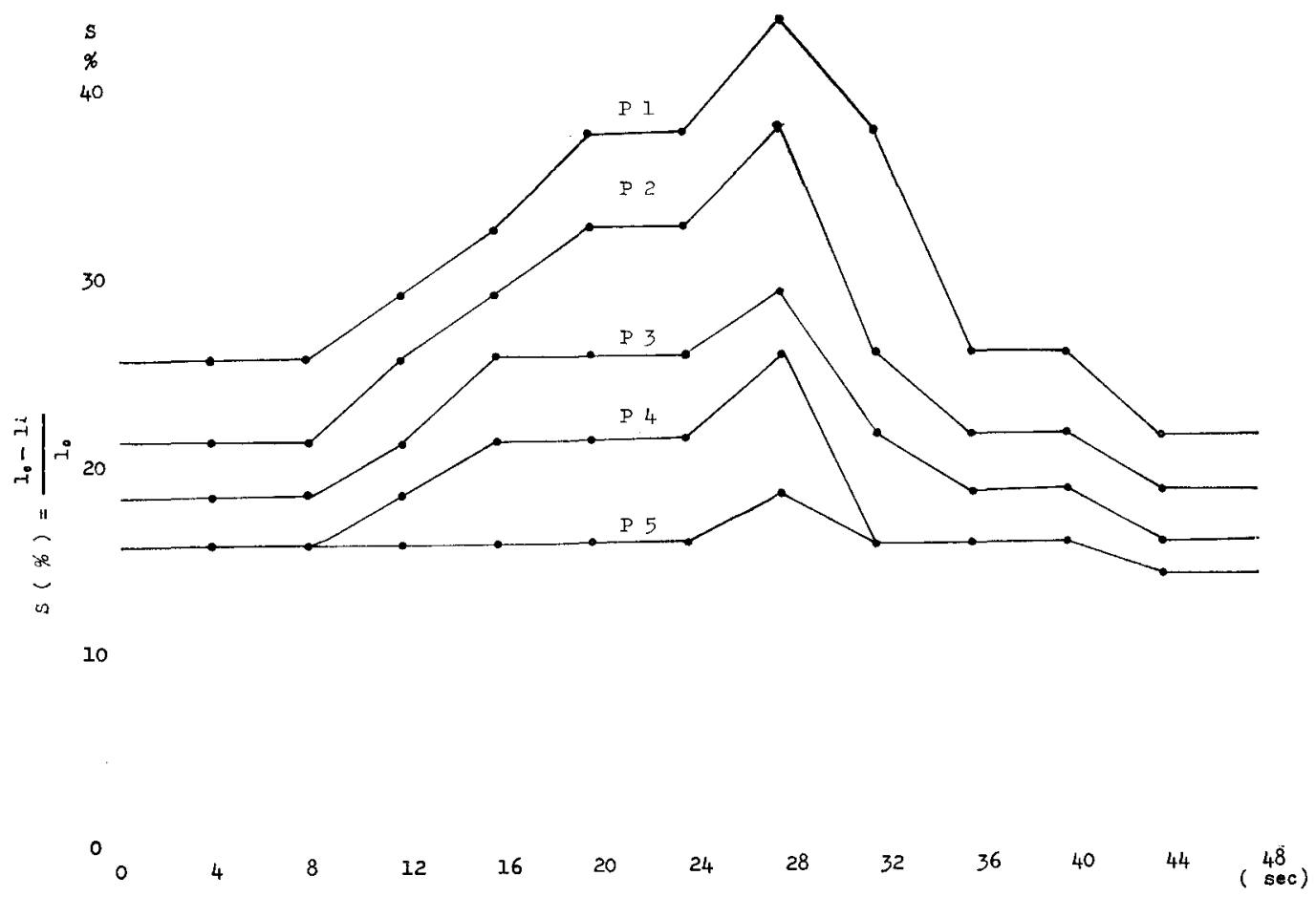

Fig. 10. Diagram showing "decremental" propagation of the spontaneous contraction of Diadumene acontium. The curves $\mathrm{P}_{1}$ to $\mathbf{P}_{5}$ represent the degree of contraction of each part at the times indicated in the abscissae. The ordinates show the rate of contraction (S). 
increase in the contraction rates of all 5 segments of the filament is recognized. In this case, possibly the contraction propagated throughout the filament from the proximal to the distal segment (P1 to P5) during 4 seconds. Thus, the propagation rate was determined as follows,

$$
\begin{aligned}
& V_{1}=s_{1} / t=\frac{1000 \mu \times 4}{4}=1000 \mu / \mathrm{sec} \text {. (P1 to P4, at } 12 \mathrm{sec} \text {.) } \\
& V_{2}=s_{2} / t=\frac{1000 \mu \times 2}{4}=500 \mu / \mathrm{sec} \text {. (P1 to P2, at } 20 \mathrm{sec} \text {.) } \\
& V_{3}=s_{3} / t=\frac{1000 \mu \times 5}{4}=1250 \mu / \mathrm{sec} \text {. (P1 to P5, at } 28 \mathrm{sec} \text {.) }
\end{aligned}
$$

(length of one segment is $1000 \mu$ )

In the same way, the mean propagation rate of 8 acontial filaments was determined as $680 \pm 260 \mu / \mathrm{sec}$.

\section{Discussion; Spontaneous Contractile Activity and its Propagation}

(A) Spontaneity. The isolated acontial filament of Diadumene may show maximum coiling (three-dimensional coiling) as shown Fig. 11 when sudden illumination is applied. Also, when it is agitated by a current of sea water from a pipette, the same

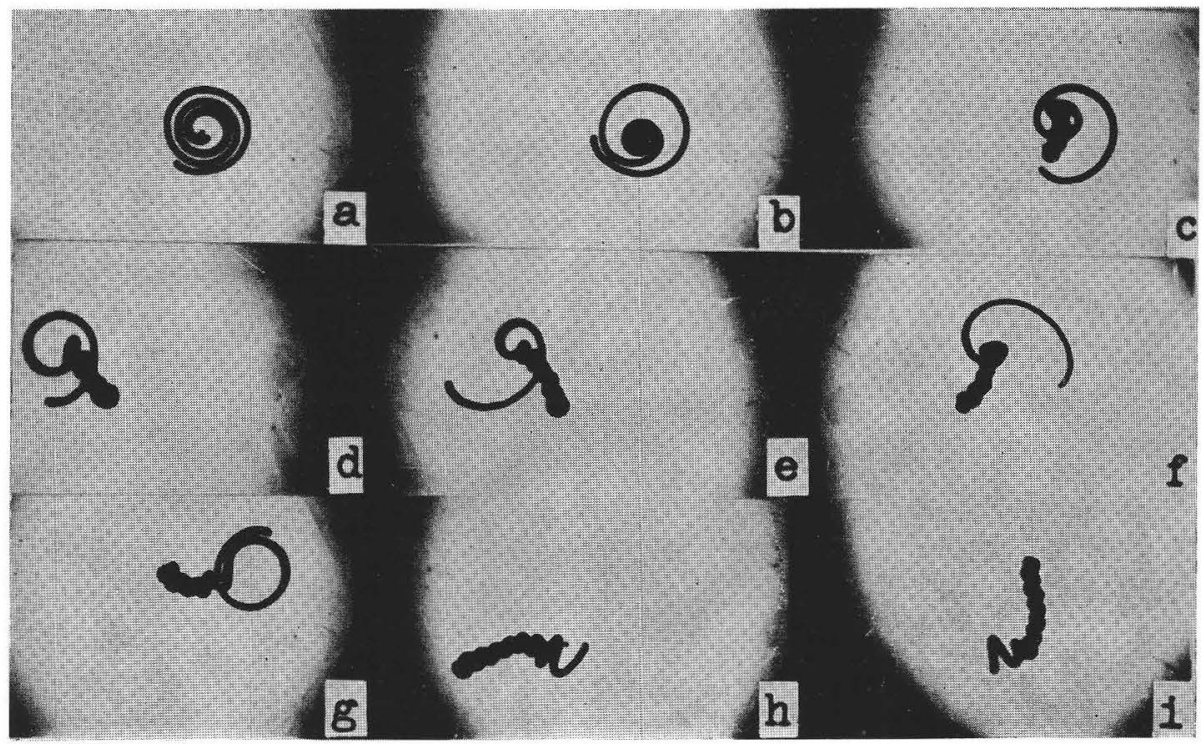

Fig. 11. Strong coiling of a Diadumene acontium lying freely in sea water. The proximal end of the filament is at the center of the coil in (a). Strong coiling begins at the proximal end (b) and propagates to involve the more distal part (c-i). Photographed at 5 -second intervals after beginning of illumination $(\times 8)$. 
response is induced. However, the semi-rhythmic contractile activities of the acontia continue under constant artificial light (about 400 lux) even when mechanical effects such as agitation or stretching are avoided, suggesting that the semi-rhythmic activity of the isolated acontial filaments is not the result of responses to external stimuli.

(B) Junctional Facilitation. In the first place, it may be pointed out that the propagation is very slow. It is suggested that the slow propagation may be depend on numerous junctions in the nerve pathway and on their prolonged junctional delay. Next, the propagation range increases in association with the contraction rate of the muscle of the proximal part of the filament. The relation between the contraction rate and the range can be indicated in a diagram (Fig. 12). Thus, it is suggested that a

28
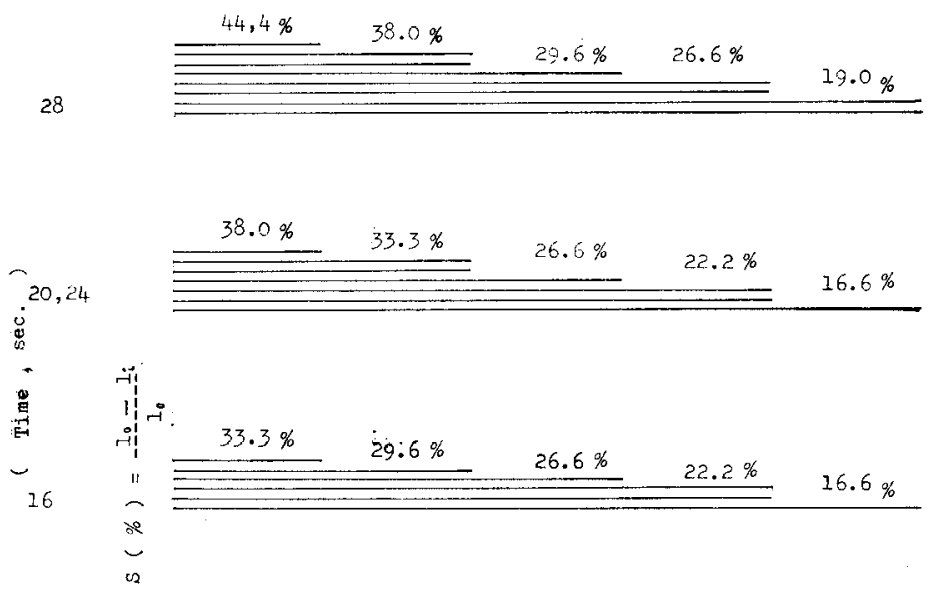

12
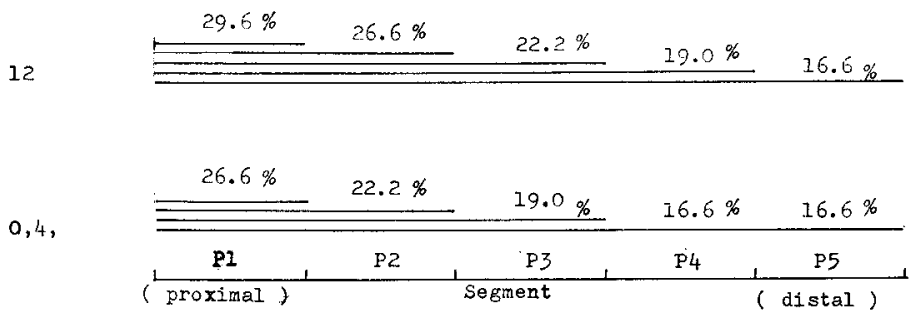

Fig. 12. Histogrammatical representation of increasing propagation ranges associated with increase in muscular contraction of the proximal part of one spontaneous contracting acontial filament of Diadumene. The histograms show the contraction rate $(\mathrm{S})$ of each part of the filament $\left(\mathrm{P}_{1}\right.$ to $\left.\mathbf{P}_{5}\right)$ photographed at 4 -second intervals. $P_{1}$ shows the first proximal part, $\mathbf{P}_{2}$, the second and so on.

certain nerve cell in the proximal part fires repetitively during a short time and these firing impulses evoke the facilitated propagation of the contraction, and that they induce a strong summation of the muscle contraction of the proximal part which exceeds that of the distal part. The propagation range of the contraction depends on the 
number of impulses which travel successively through the neuro-neural junctions in the manner of facilitation.

(C) Pace-maker System. The fact that all the cut pieces of the Diadumene acontium show spontaneous contractile activity indicates that the capacity for such activity is latent throughout the whole acontium. On the other hand, the observation that the spontaneous contractions always begin from the proximal end of the pieces suggests that this region includes a pace maker.

Thus, it is considered that the firing may occur in a cell or cells in the proximal pole of the acontium with a higher frequency than the firings at its distal pole. Moreover, two alternative firing patterns may be considered, either of which would con-
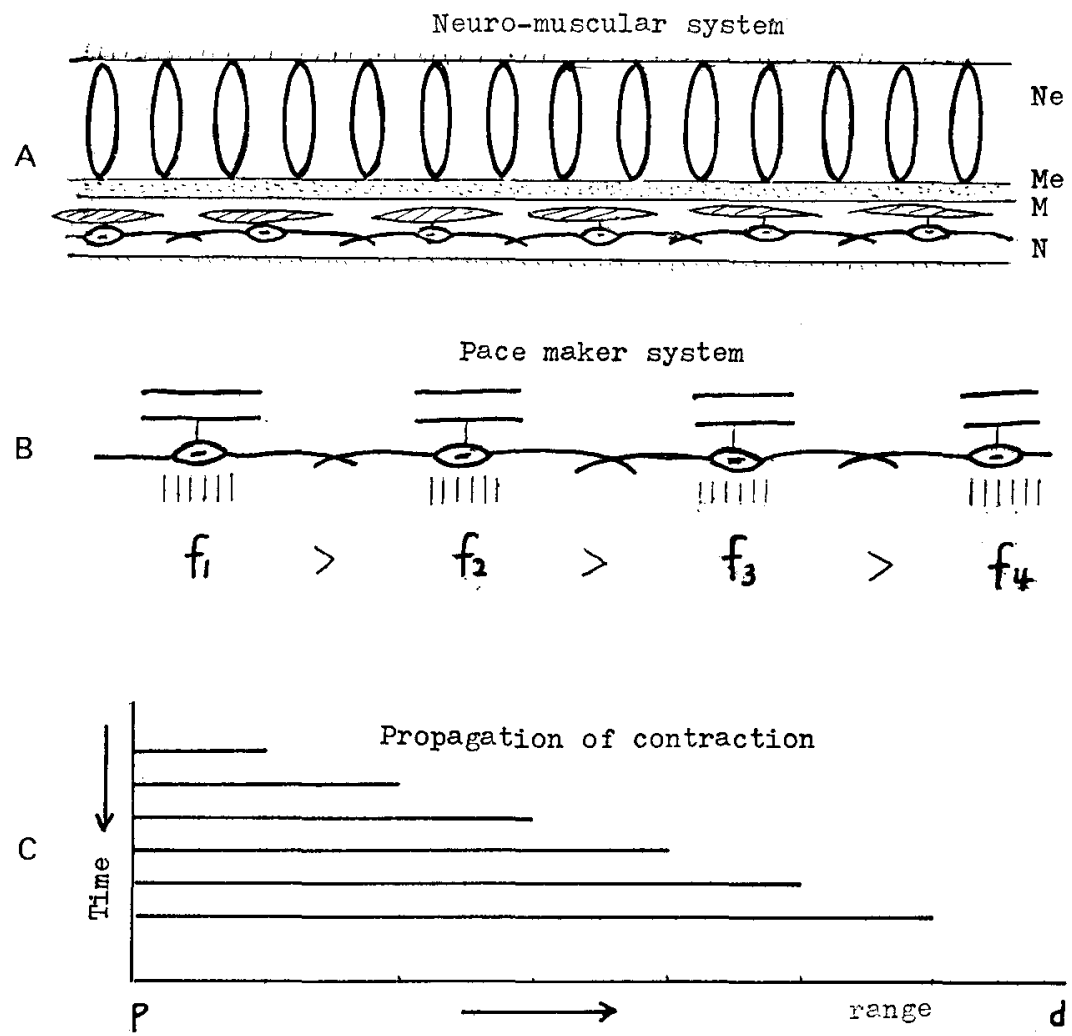

Fig. 13. Schematic representation of proposed junctional propagation in spontaneous contractile activities of the acontial filament. A. Diagram of the neuro-muscular system of the acontium. Ne; nematocyst, $\mathrm{Me}$; mesogloeal axis. $\mathrm{M}$; epithelial muscle fiber, $\mathrm{N}$; bipolar nerve cells. B. Suggested pace-maker system in which the firing frequency (f) of the nerve cells diminishes progressively from the proximal end of the filament $\left(f_{1}>f_{2}>f_{3}\right.$ $>$ etc). C. Diagrammatical representation of facilitated propagation. Arrow directed downwards shows time increase from beginning of contraction. Arrow directed to right shows propagation of range of contraction from proximal part (p) to distal part(d) of the filament. 
stitute a pace-maker of the observed acontial contractions. One possibility is that the frequency of the impulses in each burst from the proximal part is higher than from the distal part of the acontium. The other is that the frequency of burst occurrence is higher in the proximal than in the distal part of the acontium. Direct recording of the firing potentials is necessary to decide between these possibilities.

The duration of the contraction phase obtained from observation of the semirhythmic contractile activities of Diadumene acontium may be related to the duration of the firing (or the burst) of the pace-maker, and the frequency of the semi-rhythmic contractile activities of the acontium may also be determined by the frequency of occurrence of the firing (or the burst).

One factor which may explain why the proximal part works as the pace-maker is that growth of the acontium takes place in this part of the filament. In consequence, the basal cells are progressively younger than those located more distally all along the acontium, and would be expected to show a higher level of activity than do the older cells. It is suggested that this gradient of general activity is expressed in the higher incidence of firing from the proximal as compared with the distal part of the acontium at all levels along the filament.

\section{Summary}

1. The longitudinal muscle fibers of the acontium of Diadumene and Metridium are recognized in the form of tape-like bundles constructed ffom a single layer of epithelial muscle fibers. Their contraction causes bending of the acontial filament toward the "ventrum", which results in its coiling.

2. The "nerve cells" of the Diadumene acontium were stained with reduced methylene blue by MCConnelL's method (1932). Their size and shape are rather similar to the nerve cells in the living mesentery of Metridium, as reported by PANTIN and TRBSON (1960).

3. The acontial filaments exhibit not only contractile responses to external stimuli, especially sudden illumination, but also semi-rhythmic muscular contraction which takes place even when they are left undisturbed under constant ambient light.

4. A spontaneous semi-rhythmic contraction propagating from the proximal toward the distal end along the whole length of the filament makes it assume habitually the shape of a spiral, loose or tight, around the origin represented by its proximal cut end.

5. A simple geometrical method was devised to quantitate the degree of contraction along the filament; the results obtained suggest that junctional facilitation may be involved in the process of propagation.

6. A scheme to represent the functional organization of muscular activities in the acontial filament is presented. 


\section{Acknowledgement}

The writer wishes to express her sincere thanks to Dr. J. C. DAN for reading the manuscript.

\section{REFERENCES}

Batham, E. J., Pantin, C. F. A., and Robson, E. A., 1960. The nerve-net of the sea-anemone, Metridium senile: The mesenteries and the column. Quart. J. micr. Sci., 101: 487-510.

Carlgren, O. 1893. Studien über nordische Actinien. K. Sv. Vet. Akad. Handle. 25: 1-148.

Hertwig, O., und Hertwig R., 1879. Die Actinien anatomisch und histologisch mit besonderer Berücksichtigung des Nervenmuskelsystems untersucht. Jena. Zeit., 13: 457-640.

MacConnelL, C. H. 1932. The development of the ectodermal nerve net in the buds of hydra. Quart. J. Micr. Sci., 75: 495-509.

PARker, G. H., and Tirus, E. G., 1916. The structure of Metridium (Actinoloba) marginatum MiLnEEDWARDs with special reference to its neuro-muscular mechanism. J. exp. Zool. $21: 433-459$.

WADA, T., 1972. Contractile activities of the acontial filaments of Metridium senile var. fimbriatum Verrill. Jour. Fac. Sci. Hokkaido Unv. Ser. VI, Zool. 18 (3): 387-399.

WADA, T., 1972. Contractile activities of the acontial filaments of Diadumene luciae. (in manuscript).

Yanagita, T. M. and WAdA, T. 1959. Physiological mechanism of nematocyst responses in seaanemone. VI. A note on the microscopical structure of acontium, with special reference to the situation of cnidae within its surface. Cytologia. 24: 81-97. 
EXPLANATION OF PLATE I

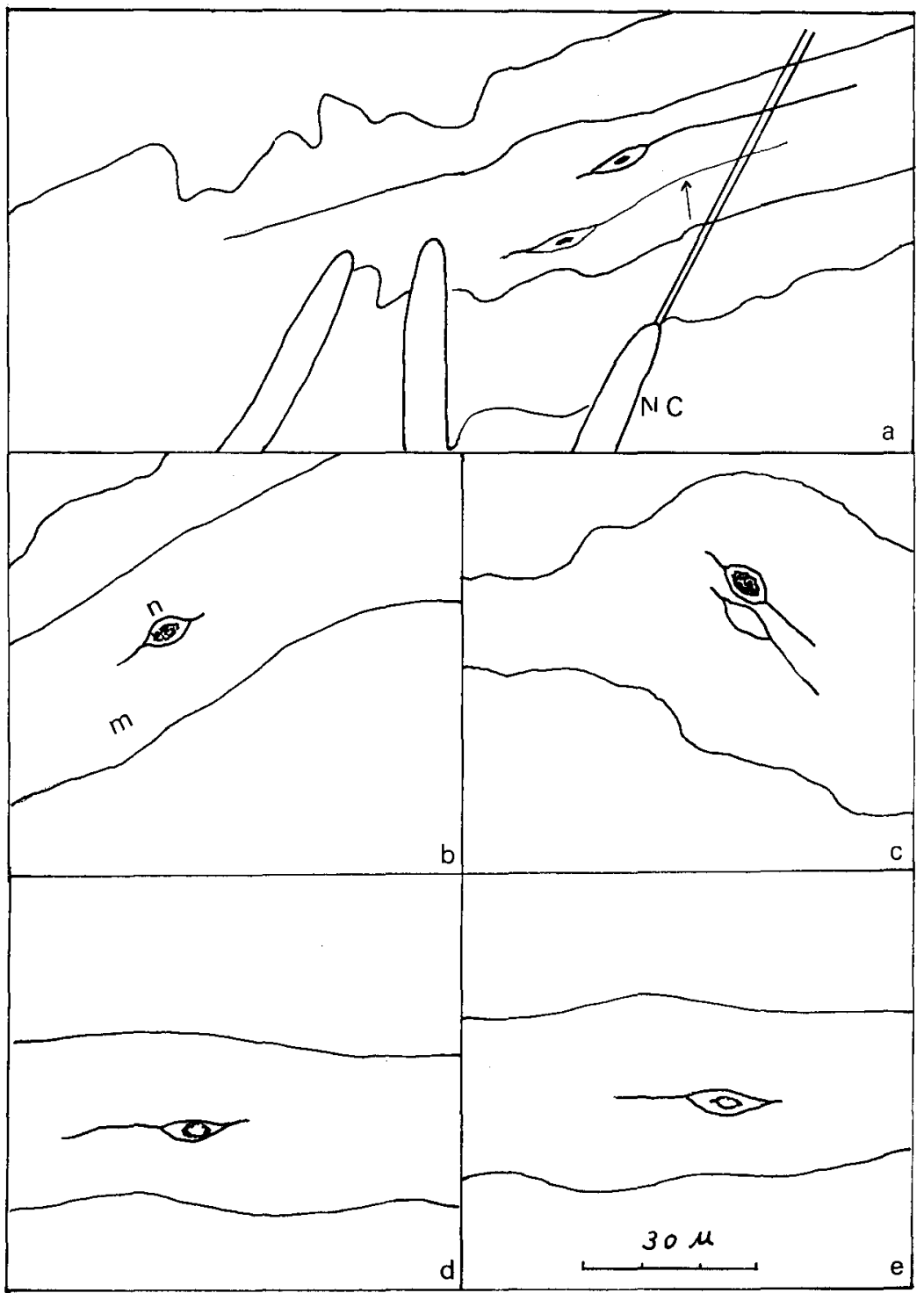

a. The "neurite" of the cell (arrow) is about $30 \mu$ in lenght. Half parts of three nematocysts are seen (N C). The cells show bipolar shape. The soma of the cell is about $10 \mu$ in length and about $3 \mu$ in width. The acontium was crushed under a cover slip by gentle pressing.

b. One "nerve" cell (n) lying on the mesogloeal band (m).

c. Two adjacent "nerve" cells.

d-e. The features such as large nucleus surrounded with small granules are seen. 
Proc. Second Internat. Symp. Cnidaria

PLATE I

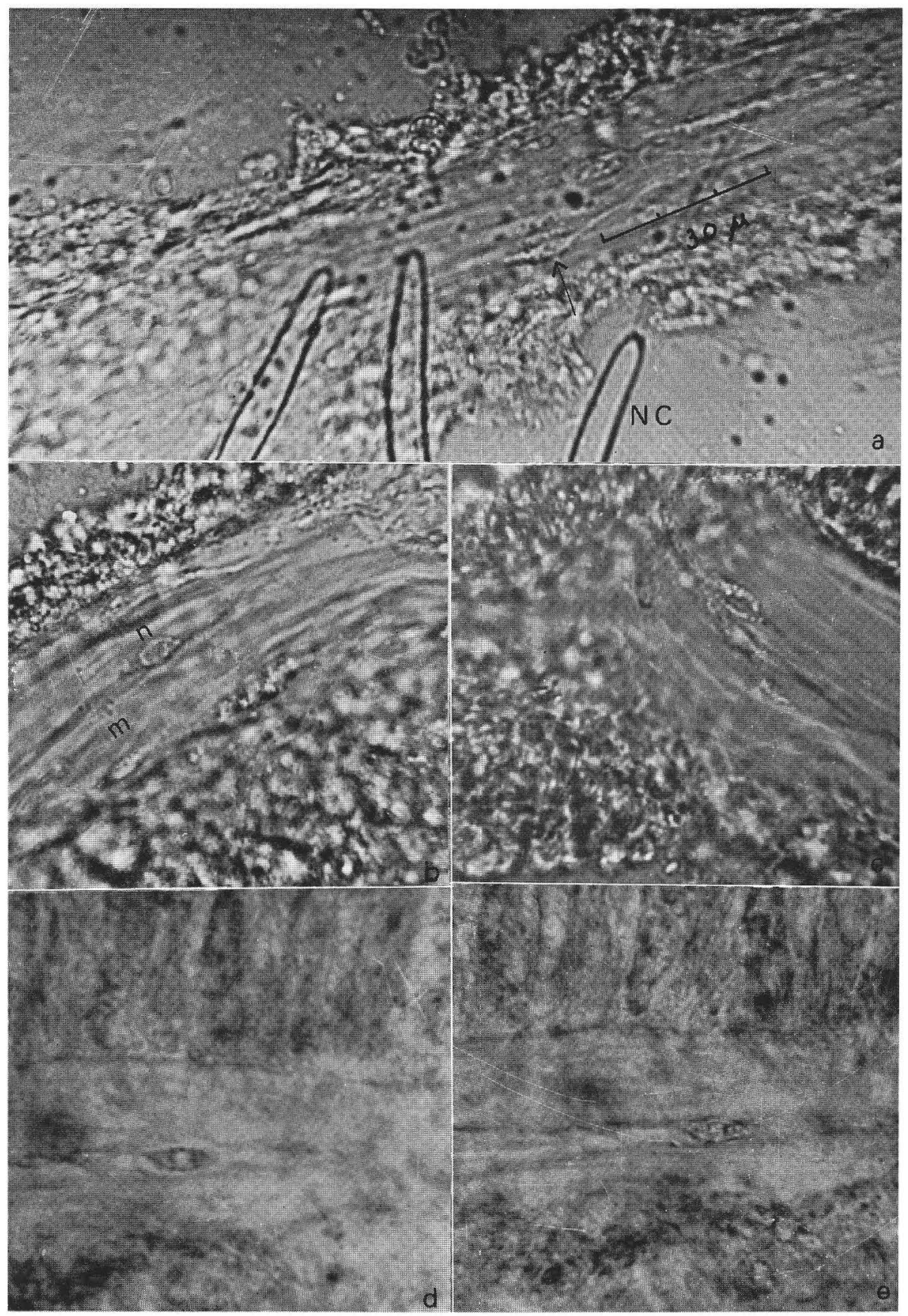

T. WADA: Muscular Activity of Acontium of Sea Anemone 